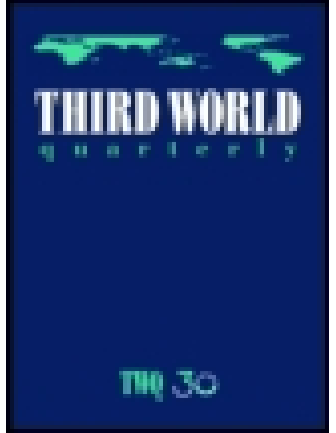

Third World Quarterly

\title{
Thinking past 'Western' IR?
}

\section{Pinar Bilgin}

To cite this article: Pinar Bilgin (2008) Thinking past 'Western' IR?, Third World Quarterly, 29:1, 5-23, DOI: 10.1080/01436590701726392

To link to this article: http://dx.doi.org/10.1080/01436590701726392

曲 Published online: 03 Dec 2007.

Submit your article to this journal $\pi$

凹 Article views: 2276

Q View related articles $\sqsubset$

4 Citing articles: 68 View citing articles ๘ 


\section{Thinking past 'Western' IR?}

\section{PINAR BILGIN}

ABSTRACT The laudable attempts at thinking past 'Western' IR should not limit their task to looking beyond the spatial confines of the 'West' in search for insight understood as 'difference', but also ask awkward questions about the 'Westernness' of ostensibly 'Western' approaches to world politics and the 'nonWesternness' of others. For there may be elements of 'non-Western' experiences and ideas built in to 'Western' ways of thinking about and doing world politics. The reverse may also be true. What we think of as 'non-Western' approaches to world politics may be suffused with 'Western' concepts and theories. Indeed, those who are interested in thinking past 'Western' IR should take an additional step and inquire into the evolution of the latter. While looking beyond the 'West' may not always involve discovering something that is radically 'different' from one's own ways of thinking about and doing world politics, such seeming absence of 'difference' cannot be explained away through invoking assumptions of 'teleological Westernisation', but requires becoming curious about the effects of the historical relationship between the 'West' and the 'non-West' in the emergence of ways of thinking and doing that are-in Bhabha's words-'almost the same but not quite'. This article looks at three such instances (India's search for nuclear power status, Turkey's turn to secularism, and Asia's integration into the liberal world order) in the attempt to illustrate how 'mimicry' may emerge as a way of 'doing' world politics in a seemingly 'similar' yet unexpectedly 'different' way.

Following revelations about the status of the scholarly discipline of International Relations (IR) as an 'American social science', 1 a "not so international' $^{\text {' }}$ if not 'hegemonic discipline', ${ }^{3}$ a 'disjunctive empire" ${ }^{4}$ and a 'colonial household', 5 it has become a commonplace to call for thinking past 'Western' IR towards discovering 'different' ways of thinking about the 'international'. 6 And what better place is there to look for 'difference' than in the 'non-West'? This article argues that this laudable project should not limit its task merely to looking beyond the spatial confines of the 'West' in search of insight understood as 'difference', but should also ask awkward questions about the 'Westernness' of 'Western' IR and the 'non-Westernness' of others. This is because there may be elements of 'non-Western' experiences and ideas built in to those ostensibly 'Western' approaches to the study of world

Pinar Bilgin is in the Department of International Relations, Bilkent University, Ankara, Turkey. Email: pbilgin@bilkent.edu.tr. 
politics. The reverse may also be true. What we think of as 'non-Western' approaches to world politics may be suffused with 'Western' concepts and theories. Indeed, those who are interested in thinking past 'Western' IR should take an additional step and inquire into the evolution of the latter. While looking beyond the 'West' may not always involve discovering something that is radically 'different' from one's own ways of thinking about and doing world politics, such seeming absence of 'difference' cannot be explained away through invoking assumptions of 'teleological Westernisation' ('they all seek to become like us anyhow!') but requires becoming curious about the effects of the historical relationship between the 'West' and the 'non-West' in the emergence of ways of thinking and doing that are 'almost the same but not quite' - to use Bhabha's turn of phrase.'

This article opens by questioning prevalent assumptions of 'difference' between 'Western' and 'non-Western' approaches to world politics. It is argued that 'Western' and 'non-Western' experiences as well as their various interpretations have, over the years, clashed and fused in so many ways that 'non-Western' ways of thinking about and doing world politics are not always devoid of 'Western' concepts and theories. The reverse may also be true. What 'we' have come to think of as 'Western' IR may contain 'nonWestern' as well as 'Western' input, notwithstanding prevalent disciplinary representations, which often sterilise the history of the 'West' by leaving out 'non-Western' challenges, interventions and contributions.

The next section considers three alternative explanations of why there is rather limited awareness in 'Western' IR of 'non-Western' ways of thinking about and doing world politics. Such explanations include foundational assumptions of neo-realism (that states can be treated as like units and that small states are of little consequence to world politics), the false promise of Area Studies (which succeeded in neither 'universalising' nor 'de-parochialising' the social sciences), and the limited number of interlocutors who could ideally have helped the 'West' and the 'non-West' to engage in conversations on IR.

In the third section the article looks at the cases of India's search for nuclear status, Turkey's turn to secularism, and Asia's integration into the liberal world order as three instances of what could be found when one looks beyond the 'West' in search of other ways of thinking about and doing world politics. Whereas contemporary attempts at thinking past 'Western' IR look for 'difference' when analysing the 'non-West', these three examples of doing world politics in a manner that is 'almost the same but not quite', suggest that 'mimicry' may be a way of 'doing' world politics in a seemingly 'similar' yet unexpectedly 'different' way.

\section{Problematising assumptions of 'difference'}

Challenging students of International Relations to think past its 'ethnocentric, masculinized, northern and top-down' ways, Ken Booth encouraged them to question 'the extent to which our sense of what we do as academics would have been different had the subject been founded in universities not by 
a Liberal MP in mid-Wales (David Davies) in the aftermath of the Great War, but instead by Dr Zungu, the admirable feminist medic she-Chief of the Zulus'.

Booth's words rest on assumptions of 'difference': that the 'non-West' offers a 'different' take on world politics - if only 'we' could find out more about it. Without wanting to underplay the importance of his point regarding the parochialism of universalism espoused by 'Western' IR (not to mention IR's ethnocentric and masculinised take on world politics, which Booth also problematises), it is significant, for the purposes of the argument here, to consider the possibility that one's efforts to think past 'Western' IR are not guaranteed to get one to a place where 'different' ways of thinking about and doing world politics preside. ${ }^{9}$ This is because 'Western' and 'non-Western' dynamics as well as their interpretations have, over the years, clashed and fused in far too many different ways - ways that are not always acknowledged. While the role played by the 'West' in inventing the 'Third World', the 'Orient" ${ }^{\text {"1 }}$ and 'Africa" 12 is reasonably well documented, the former's debts to the latter are little known. ${ }^{13}$ Franz Fanon reminds us that it is Europe that 'is literally the creation of the Third World' in the sense that it was 'the sweat and the dead bodies of Negroes, Arabs, Indians and the yellow races' that have fuelled its 'opulence'. ${ }^{14}$ Likewise, Amartya Sen warns against 'praising an imagined insularity'. 'Given the cultural and intellectual interconnections in world history', he writes, 'the question of what is "Western" and what is not would be hard to decide., 15

If the world has remained oblivious to such interconnections, this is partly because the 'West' has usurped not only the material resources of the 'nonWest' but also its image of itself as a subject, as opposed to a mere object, of history. ${ }^{16}$ Particularly insightful for the argument here is Timothy Mitchell's re-presentation of modernity not as a 'stage' but as a particular way of 'staging' history. Rejecting both representations of modernity as a product of the 'West', and the revisionist accounts that view modernity as a product of the encounter and interaction of the 'West' with the 'non-West', Mitchell makes a case for understanding it as a particular way of 'staging' history that erases the 'plural genealogy and ecology' of the overall process of the production of 'modernity'. He writes:

The identity claimed by the modern is contaminated. It issues from too many sources and depends upon, even as it refuses to recognize, forebears and forces that escape its control. To overlook these differences requires a constant representing of the homogenous unity of modernity's space and time. ${ }^{17}$

The examples of such erasure highlighted by Mitchell include the 'nonWestern' origins of ostensibly 'Western' ideas such as 'modernism' (in 1890 by a 'Nicaraguan poet, writing in a Guatemalan journal, of a literary encounter in Peru'); 'postmodernism' (born in the 1930s Hispanic world, introduced to the USA by Ihab Hassan, 'the son of a provincial governor in Egypt'); 'the population' and 'culture' (both 'probably first occurred in the colonized non-European regions'), and 'liberalism' (in the evolution of 
which India "played a sustained role...[by] exposing it to a constitutive ambivalence'). ${ }^{18}$

An IR example of such 'imagined insularity'19 could be found in the 'democratic peace' literature, which rests on assumptions regarding the theory and practice of democracy being products of the 'West', often oblivious to the ways in which liberal democracy (as with capitalism) has had multiple places of birth ${ }^{20}$ - not to mention the historical relationships of war and intervention, which have helped to keep the zone of 'democratic peace' 'peaceful' and 'democratic', while allowing other parts of the world to remain 'not-so-peaceful' and 'not-so-democratic'. ${ }^{21}$ As they overlook the (unintended) consequences for the 'non-West' of the emergence of 'democratic peace' in the 'West', IR scholars lament the absence of liberal democracy in these areas which, they worry, render difficult (if not impossible) the emergence of democratic peace world-wide. While capturing such interconnections requires becoming aware of and acknowledging the role played by modernity not as a stage but as a way of 'staging' history, contemporary accounts often write back into history the current stalemate between radical elements of the 'West' and the 'non-West' with an admixture of 'culturalist' rationale. $^{22}$

Perhaps more significantly, IR, as studied in the USA, not only fails to capture such historical relationships but has also been complicit in shaping them. While the consequences of the hegemonic aspirations of the USA for the development of disciplinary social sciences, ${ }^{23}$ political science ${ }^{24}$ and International Relations ${ }^{25}$ have been recognised, very little is known about how such dynamics have affected ways of thinking about and doing world politics elsewhere. The spread of US approaches to other parts of the world, which gained pace in the postwar era, is often explained with reference to the emergence of the USA as the 'dominant producer of both ideas and things', ${ }^{26}$ which coincided with and provided a basis for the modernisation and/or Westernisation projects of elites in various parts of the world. ${ }^{27}$

However, seeking answers in assumptions of 'teleological Westernisation' as such does not suffice. Those concepts and theories that travelled from the 'West' to the 'non-West' and the channels through which they travelled (mostly through US-sponsored scholarships and grants to 'non-Western' individuals and institutions) were not unrelated to US interests; nor were they independent of US policy making. These concepts and theories provided back-up to US policy making in at least three ways: first, by directly informing US policy making towards the 'non-West'; second, by providing the tools with which 'non-Western' actors could set up their own 'modernising nation-states' and/or 'national security states'; and third, as ideological tools that rendered 'natural' the policies adopted and implemented in the 'West' and the 'non-West'.

During the early postwar period concepts and theories developed by US scholars working on 'modernisation' and 'development' were exported to the 'non-West' through scholarships and fellowships or bilateral training and exchange programmes available to students, scholars and policy practitioners. Policy makers in different parts of the world have invariably 
embraced 'modernisation' and/or 'national security' as policy tools. Even in those places such as India or Egypt where US political influence was met with scepticism, the influence of US-originated concepts such as 'security' and 'development' was undeniable. 'National security' was utilised

in India's case, providing a basis for building a regional hegemonic order; in the case of Pakistan, providing a raison d'être for that country as a separate homeland. Given these two meanings, 'national' security is correlated with different articulations of political space in the region. In Gramscian language the national security project in Pakistan serves legitimation purposes, albeit not very successfully. By contrast, India has sought regional leadership in the name of national security. ${ }^{28}$

One specific product of such synergy between the US scholarly community and the policy world has been models of military-led development, which were popularised during this period. During the 1950s, as US policy making increasingly turned towards 'non-Western' militaries as allies in maintaining stability in the 'Third World' (thereby recalibrating civil - military balances to the benefit of the latter), US scholarly writings provided the rationale. The main difference between policy making and scholarly approaches was that

whereas policymakers appeared content to identify the reasons for endorsing greater involvement of the US military and its local counterpart in Development programs, policy scientists and those who regarded themselves as allied theoreticians of Development rationalized the role in romantic terms. ${ }^{29}$

These scholars were not prepared to advocate a militarisation of politics. Instead they provided a 'rationale rich in psychology and history' as to why civilians in the 'Third World' suffered from a 'post-colonial syndrome' that led them to react against the 'West', whereas 'a sense of security' seemed to enable military leaders to 'accept the weakness of their countries in relation to the West'. Such ostensibly 'scientific' basis, in turn, allowed scholars to propagate 'myths of Development that simultaneously supported the view of the military as models of democratic, non-authoritarian training while arguing that the militarization of politics was an undesirable failure of Third World politics' ${ }^{30}$

Thus US-originated understandings and practices of 'national security' and 'development' were exported to 'non-Western' locales in a context characterised by the convergence of the US national security agenda of maintaining stability by way of encouraging military-led modernisation, and of the 'non-Western' actors' agenda of seeking security through sovereign development. Whereas US policy makers and the scholarly community provided the logistical and conceptual back-up, local actors stepped in to shape domestic political processes in line with their own preferences. It is an ironic twist of history that those ostensibly 'Western' concepts such as 'national security', 'sovereignty' and 'development', which have helped make these 'non-Western' 'realities' are now found wanting in providing scholarly explanations of the very same 'realities'. 
The broader argument here is that 'non-Western' insecurities did not evolve in a vacuum. They evolved through interaction with the USA-its ways of thinking about and doing world politics. These relationships made their mark on US IR as well. Scholarly writings did not merely inform practice; they were also shaped by the policy context. Even those scholars who shied away from establishing explicit ties with the policy world could not prevent their studies from being shaped by the 'enemy' or 'friend' images fashioned for and through foreign policy practices. Such images and assumptions informed ostensibly 'objective' accounts, thereby shaping US ways of thinking about and doing world politics. ${ }^{31}$

It is this web of relationships between the 'West' and the 'non-West' (and their ways of thinking about and doing world politics) that renders problematic the expectations of finding 'difference' in the 'non-West'. This is not to deny the diversity in the experiences and priorities of the 'West' and the 'non-West'. Rather the aim here is to point to the problems involved in the efforts to look towards the 'non-West' in search for radical 'difference' while overlooking the factors and actors that help produce ways of thinking about and doing world politics in a manner that is 'almost the same but not quite'. This point will be further developed in the following section, which considers alternative explanations of to why 'Western' IR offers so little about 'non-Western' ways of thinking about and doing world politics.

\section{Why does IR offer so little about the 'non-West'?}

Three alternative explanations will be considered: the prevalence of neorealist assumptions that do not encourage students to be curious about 'nonWestern' parts of the world; the false promise of Area Studies, which failed to work with the disciplines to allow for cross-fertilisation to occur; and the relatively small number of interlocutors who could ideally have set up conversations between the 'West' and the 'non-West'. Each explanation will be treated in turn.

\section{The disciplinary straightjacket of neo-realism}

IR (especially its neo-realist variant) has not always been interested in the world beyond the great powers. 'Denmark does not matter' quipped Kenneth Waltz, underlining the marginality of smaller states to system theorising. ${ }^{32}$ This is not only because those who are in the peripheries of world politics are also relegated to the peripheries of one's thinking. It is also because neo-realism teaches students of International Relations to focus on great powers and think of them as like units, the internal dynamics of which are of little consequence for world politics. The choices made in favour of conducting state- and great power-centric analyses have had implications for 'Western' IR. Throughout the years critical scholars have been documenting the implications of such methodological and epistemological choices, ${ }^{33}$ thereby preparing the groundwork for the project of thinking past 'Western' IR. 
Whereas students of the 'Third World' have long warned about what Baghat Korany referred to as the 'increasing irrelevance' of 'standard' concepts and theories in explaining the dynamics of non-Western locale, ${ }^{34}$ 'Western' approaches, even as they focused on the 'non-West', have failed to be fully relevant to the concerns of people, states and societies in the 'nonWest'. This is because analyses of 'sage bush wars', 'low intensity conflicts' and 'guerrilla wars' focused on and thus were able to capture only the threat perceptions and interest calculations of the 'West'. Put differently, the 'nonWest', even when it was made the focal point of IR, was not treated as the referent object (what/who needs protection). ${ }^{35}$

In those instances when they became the focal point of analyses, "nonWestern' states (and non-state actors) were slotted into one of the two roles that were available. Either they were considered as part of the 'established paradigm, and assigned the role of junior-partners in the power game' or they were labelled 'trouble-makers', thriving on 'nuisance power', fit for the exercise of counter-insurgency techniques discussed in the literature. ${ }^{36}$ Although this has begun to change in recent years, with more attention being paid to the insecurities of individuals, social groups and states in the developing world (as with the emergence of concerns about and the literature on 'human security'), the inordinate amount of attention paid to 'state failure' should serve as a reminder of the persistence of the aforementioned dynamics (of putting 'Western' insecurities first when studying ostensibly 'non-Western' dynamics). For, although the shift in mainstream security analyses from purely military to broader 'human security' concerns may be considered a 'good thing', state 'weakness' is still portrayed as a problem by virtue of 'weak' states' inability to prevent their territories from being used as a safe harbour by terrorists - not because those states fail to deliver the necessary goods and services to their citizens. So-called 'strong' states of the 'non-West', in turn, even when they fail to prioritise their citizens' concerns, are not considered to be a problem as long as they remain attentive to 'Western' security interests. ${ }^{37}$

To recapitulate, one explanation as to why 'Western' IR has produced relatively little about 'non-Western' ways of thinking about and doing world politics has to do with the disciplinary straitjacket imposed by IR as a social science, in that students of world politics have not been socialised into being curious about the 'non-West' but have been encouraged to explain away 'non-Western' dynamics by superimposing 'Western' categories.

\section{The false promise of Area Studies}

The promise of Area Studies, when it was initially founded in the late 1940s, was that of making the social sciences a 'whole' and their findings of 'universal' relevance by providing data about 'non-Western' parts of the world. Thus the political scientist Gabriel Almond called on his colleagues to study the 'uncouth and exotic' regions of the world in order to make political science a 'total science'. ${ }^{38}$ In time this division of labour between the students of disciplines and areas became a hierarchical one. In a manner reminiscent 
of the 'upstairs, downstairs' dynamics of a colonial household, ${ }^{39}$ disciplinary generalists looked down upon their Area Studies colleagues, who produced the 'thick descriptions' they needed to theorise grandly about the world. One unfortunate outcome of the institutionalisation of this hierarchical division of labour in 'Western' IR has been the failure of Area Studies to fulfil the task of making the social sciences less parochial and more 'universal'.

Leaving aside the issue of the desirability and/or feasibility of such a task, what should be noted here is that, in time, efforts came to focus almost exclusively on representing the 'non-West' as part of an ostensibly 'universal' story told in and about the 'West'. ${ }^{40}$ Whereas the original task would have required disturbing the unquestioned dominance of 'Western' ways of knowing, in time efforts were directed towards adopting and 'testing' those frameworks that were developed in the 'West'. Ideally, such testing should have allowed for further development of the theories at hand, thereby contributing to the project of achieving 'universal' knowledge. However, the overbearing authority of the disciplines made it very difficult for Area Studies scholars to penetrate the disciplines.

One implication of the entrenchment of this hierarchical division of labour has been the emergence of a body of work that explicitly or implicitly rejects the relevance of 'theory'. This, in turn, is mostly the result of a frustration with the limited relevance of existing analytical frameworks while IR continues to gloss over cultural-historical context, ${ }^{41}$ an (unintended) consequence of which is the limited relevance of 'Western' concepts and theories in understanding 'non-Western' (and global) dynamics.

\section{Interlocutors are in short supply}

A third explanation as to why knowledge about the study of IR in the "nonWest' has remained limited has to do with the inadequate number of interlocutors from the 'non-West' who could have informed their 'Western' counterparts about ways of thinking about and doing world politics in their own locale. Working at institutions far away from the disciplinary discipline exercised by both neo-realism and the hierarchical division of labour between disciplinary IR and Area Studies, 'non-Western' scholars could be considered ideally situated to thinking past 'Western' IR and producing 'different' insights. Nonetheless, the limited number of studies espousing such 'difference' suggests that the study of world politics in the 'non-West' may not have transpired as expected: what is found in 'non-Western' scholars' treatises on world politics is not always radical 'difference' (as is expected of them) but 'similarity'. ${ }^{42}$

In 'non-Western' scholars' work 'similarity' emerges as research that has been filtered through 'Western' concepts and packaged in 'Western' categories. Some have explained the emergence of ways of thinking and doing that are 'almost the same but not quite' with reference to the training many 'non-Western' scholars receive. They are, to use Donald Puchala's choice of words, 'social science socialized products of American graduate schools ${ }^{43}$ that presumably cannot be anything other than what they have 
been taught. There may be an element of truth to this characterisation in that being exposed to US or other 'Western' training in IR leaves its mark on the thinking as well as professional practices of its students. Yet it is important not to slip from pointing to the effects of 'Western' IR on 'non-Western' scholars to assuming that they have 'thoroughly digested the norms and parameters of Western IR'. ${ }^{44}$ Whereas the former allows the possibility of scholars to be other than what they are taught (as with some 'Western' institutions choosing to encourage their students to think past 'Western' IR), the latter does not.

Frustrated with what they consider to be 'social science socialized' IR scholars from the 'non-West' and in search of 'difference', some 'Western' scholars have turned to 'Third World radicals ${ }^{\text {'45 }}$ and found exactly what they were looking for: treatises on the various ways in which the strong have exploited the weak. Others who turned to non-IR sources such as literature, drama and philosophy ${ }^{46}$ found alternative 'visions and articulations of relations between political communities'. ${ }^{47}$ Without wanting to underestimate the significance of inquiring into such radically 'different' visions of security and community, it is nevertheless important to underscore one issue: the ways in which the current state of 'non-Western' IR ('almost the same but not quite') is taken for granted and not problematised is in itself problematic. This is not least because such a stance rests on two prevalent assumptions: 1) 'difference', which is the default position of the 'non-West'; and 2) 'teleological Westernisation', ie the notion that Westernisation is a desirable if not inevitable end-point for the 'non-West'. These two assumptions tell students of IR to expect those who are in a position of 'weakness' to have radically 'different' ideas compared with those who are in a position of 'strength' - as they often do. However, when 'non-Western' scholars' writings do not exhibit such 'difference' but appear to be similar to those of their 'Western' counterparts, 'non-Western' scholars are represented as the robotic 'Stepford Wife' to 'Western IR', the engineer. ${ }^{48}$ There is no puzzle for anyone it seems, in the former's adoption of those 'standard' concepts and theories developed by and for the purposes of the latter. They are 'social science socialized products'49 of 'Western' IR who have 'thoroughly digested [its] norms and parameters'. ${ }^{50}$ Needless to say, such a stance denies agency to 'non-Western' scholars and represents them as unthinking emulators.

The emergence of ways of thinking and doing that are 'almost the same but not quite' in and through 'non-Western' scholars' studies is worth inquiring into not least because such works may be treated as a subject of analysis in their own right and interpreted as yet another instance of 'mimicry'. That is to say, while what 'non-Western' scholars 'say' about world politics may not be found to be of interest, how they say what they say-ie through the adoption of 'Western' concepts and categories - is nevertheless worth inquiring into. ${ }^{51}$

The same point could be made regarding non-Western actors' practices in general, which, in turn, would allow going beyond unthinking assumptions of 'teleological Westernisation'. Interestingly, even the critics of such 
assumptions who point to the workings of 'Western' hegemony are not immune to 'epistemological Orientalism' in that they explain 'mimicry' with reference to a 'Western masculinist capitalism' that 'absorbs if not obliterates, pre-capitalist forms of production, consumption and hegemony'. ${ }^{52}$ The following section looks at three instances of 'mimicry' in 'non-Western' practices of world politics and seeks to point to the agency and agenda of the 'non-Western' that are overlooked by 'standard' accounts.

\section{Postcolonial insights}

For those who remain curious about the emergence of 'similarity' as well as difference in/by the 'non-West', a particularly useful key is provided by postcolonial studies. Bhabha's concept of 'mimicry' helps us to ponder the rationale behind the 'non-Western' search for 'similarity'. Rejecting the short-cut offered by assumptions of 'teleological Westernisation', Bhabha introduces the concept of 'mimicry' as 'the sign of a double articulation; a complex strategy of reform, regulation and discipline which 'appropriates' the Other as it visualises power. Mimicry is also the sign of the inappropriate, however, a difference or recalcitrance which coheres the dominant strategic function of colonial power, intensifies surveillance, and poses an immanent threat to both 'normalised' knowledges and disciplinary powers'. ${ }^{53}$

Introducing the concept of 'mimicry' to IR, Ling underscores the 'survival' instinct of the colonized. Mimicry, writes Ling:

allows the colonized to try on, like a new accessory, the colonizer's reflected image in the body/site of the 'native'. A moment of political destabilization rather than fawning flattery, mimicry subverts the hegemonic contention that the colonizer is always separate from and superior to the colonized. ${ }^{54}$

By so doing, Ling also pre-empts those critics who allege that postcolonialism reduces the 'colonized' to being nothing but that. Seeking to become 'almost the same but not quite' is not for lack of 'authentic' grounds upon which modernity can be erected, ${ }^{55}$ but for purposes of survival in the face of the 'colonizer"s authoritative claims over the right to 'better' rule, which, in turn, lays the ground for colonial conquest. By 'disclosing the ambivalence of colonial discourse [mimicry] also disrupts its authority' ${ }^{56}$ and removes the ground for the 'West' to claim the capacity and the right to better rule, thereby making room for sovereign development.

In what follows this section of the article offers three examples to illustrate how 'mimicking' 'Westernness' may emerge as a deceptively 'similar' yet altogether 'different' way of doing world politics. One advantage to this approach is that it permits recognition of the agency and agenda of 'nonWestern' actors in adopting, adapting or bypassing 'Western' ways of thinking about and doing world politics. The point is that 'non-Western' resistance and/or 'difference' may take many forms - including a search for 'similarity'. 


\section{Modernity as security: India and the nuclear bomb}

In 1974 India exploded its first 'peaceful' nuclear weapon. From 1974 until May 1998 (the year when it conducted five more tests) India remained a nuclear weapons-capable state that respected the test-ban treaty, negotiated at various non-proliferation fora and did not officially announce its nuclear power status. Neo-realist accounts of India's 1974 and 1998 tests see little to be puzzled about, portraying them as security-seeking behaviour through military means as conditioned by international anarchy. ${ }^{57}$ Those who contest neo-realist accounts, in turn, point to the absence of a direct military threat to India's security which could have justified a nuclear response. Instead, they emphasise the age-old realist concern of the 'search for power' as driving India's policies. India has sought the ability to 'influence others to behave as it wants them to and, conversely, to resist the unwelcome influence of others', maintains one author. ${ }^{58}$

Students of Area Studies who doubt the explanatory power of such conceptual categories in the Indian context emphasise domestic dynamics. While the emphasis they place upon the role of domestic leadership is illuminating in terms of understanding Indira Ghandi's search for legitimacy during the 1970s, it goes only so far in explaining India's stance towards nuclear weapons. This is because students of Area Studies as well as their disciplinary-oriented counterparts fail to ask (and answer) the following compelling questions: "why would a nuclear explosion be the means by which a leader seeks to bolster sagging support?' and 'what was so compelling about a nuclear explosion that would give a government the popular legitimacy it sought?'. ${ }^{59}$ Seeking answers to these questions as opposed to explaining away India's nuclear dynamics with reference to ostensibly 'universal' strategic reasoning (neo-realist IR's answer) or domestic political quibbling (Area Studies answer) should lead students of world politics to be curious about differences in security understanding that run below surface resemblances in behaviour.

India's relationship with the nuclear bomb suggests that both 'similarity' and 'difference' between the 'West' and 'non-West' are (re)produced through the historical web of relationships between the two as opposed to being purely 'cultural' ('Western' or 'non-Western'). Itty Abraham's study of India's nuclear bomb reveals numerous layers of such interaction between the domestic and the international, and the 'Western' and 'non-Western'. The nuclear bomb was linked with security in the minds of Indian intelligentsia, argues Abraham, not only due to (regional and global) 'power politics' concerns but also through a particular understanding of 'national security' that was 'imported' from the 'West' (read USA) in the aftermath of World War II, and served as a theory (and ideology) of the modern Indian state. In the postwar context theories of national security and development "came to set the conceptual limits to national "pathways to progress", ${ }^{60}$ understood in the 'non-West' as becoming 'modern'. Given the prevalence of the discourse of 'modernity-as-a-Western-thing' and 'Western' claims to dominate and/or rule being legitimated on grounds of being 'modern' 
(as opposed to the 'traditional' ways of others), becoming 'modern' emerged as a form of resisting the 'West', removing the grounds for future interventions or domination. Accordingly, India's nuclear bomb could be considered as a component of this security policy of locating oneself in the 'modern' world so as to remove the ground for external interference. What comes out of Abraham's account of the Indian atomic bomb is a novel use of a military instrument for purposes of non-military security in a way not anticipated by the 'Western' minds behind nuclear weapons.

\section{Secularization as security: Turkey through postcolonial lenses ${ }^{61}$}

As part of the transition from the Ottoman Empire to the Republic of Turkey, leaders of the revolutionary movement made a number of radical breaks with the past. These include the declaration of a republic and the adoption of democracy and secularism as its constitutive principles. The decision by a Muslim majority state to forego 'Islam' as one of the governing and/or legitimating principles and adopt secularism was, at the time, represented by the leadership as well as by its observers as part of an attempt to leave 'traditions' behind and become 'modern' ${ }^{62}$ True to the logic of secularisation theory, it was suggested that religion had no place in a 'modern' future and was thus to be left outside the future of Turkey.

From the perspective of neo-realism Turkey's turn to secularism would be of little interest, for it has little to do with international relations but much to do with domestic politics. From the perspective of Area Studies Turkey's secularisation emerges as a policy choice peculiar to its own dynamics and, in particular, to the Ottoman experience with 'Islam'. Those readings more attuned to 'critical' concerns recognise a 'governmentality' rationale in the decision to turn to secularism, ${ }^{63}$ but they focus purely on domestic concerns to the neglect of the historical relationship between the Ottoman Empire and the 'West'. The long-neglected international relations aspect of Turkey's secularisation has at least three dimensions. ${ }^{64}$

First, there is an international (as well as domestic) security dimension to the abolition of the Caliphate in 1922; it was abolished partly because it was complicating relations with European powers for '[t]hey either suspected Turkey constantly of scheming against their sovereignty, or else they themselves were involved in intrigue in Turkey in order to get control of the Caliphate and use it on behalf of their own ambitions'. ${ }^{65}$ Abolishing the Caliphate in 1924 removed the grounds for such future intervention into Turkey's affairs. It also removed a cloud of suspicion regarding the ambitions of the revolutionary leadership by making it clear that these were limited to the boundaries of the new Turkey.

Second, there was the problem of the claim of European powers to the right to interfere on behalf of the rather few non-Muslims left within the boundaries of the new Turkey. The grounds for making such claims had to be removed if Turkey was to sustain its existence as a sovereign state. During the Lausanne Treaty negotiations (which ended the "war of 
independence' fought against some of the victorious powers of World War I who had planned to divide up some of Turkey's territories among themselves) members of the delegations of European powers had challenged Turkey's jurisdiction over the 'minorities' (non-Muslim citizens) and wanted to maintain the right to intervene on their behalf as they did during the Ottoman times. ${ }^{66}$ Turkey's turn to secularism was partly to prevent such interference in the future.

The third international dimension to Turkey's turn to secularism emerges through a reading of Turkey's project of modernisation and of 'gaining respect in the eyes of the civilised world' as part of a solution to a security problem. As with Ottoman attempts at Westernisation, Turkey's grand project of Westernisation is almost always explained as an attempt to achieve the level of and/or join 'contemporary civilisation'. In such explanations, the 'international' dimension is acknowledged, but it is represented either as a 'lifestyle choice' or as a purely instrumental move to prevent military decline. However, both the Ottoman and Turkish Westernisations were more than that. They were attempts to become a member of 'contemporary civilisation' not only to provide an end to battlefield losses but also to remove the ground for 'European' interventions and claims to the right to rule the 'uncivilised'. Postcolonial movements around the world have had to fight not only the forces but also the culture of imperialism, ${ }^{67}$ for the latter allowed the former to occur. The culture of imperialism, together with an Orientalist mindset, ${ }^{68}$ provided the basis for the 'West's claim to enjoy 'the right to better rule' 'non-Western' peoples. It was on the basis of such claims that 'European' actors had interfered numerous times in the affairs of the Ottoman Empire. ${ }^{69}$ Viewed as such, Turkey's turn to secularism, as the centrepiece of the project of Westernisation, could be considered as a part of a strategy adopted by the leaders of the revolutionary movement to cope with a specific security problem - a strategy of seeking to become 'similar' in a world that was perceived to be not-so-hospitable to 'difference'.

\section{Integration into the liberal world order as security: Asia and the 'West'}

As IR continues to be puzzled by China's 'Red Capitalists', ${ }^{70}$ Asian actors have long sought integration into the liberal world order through Westernisation schemes of various sorts. While it is possible to explain away Asia's interactions with the 'West' with reference to 'teleological Westernisation', or by reducing it to a struggle for supremacy in a world system characterised by anarchy and cut-throat capitalism, and/or with reference to cultural characteristics, the very hybrid nature of the end-product calls for the use of tools more adept in tackling 'non-Western' similarity/difference. As yet not even the more culturally attuned International Society School is helpful in understanding Asia's integration into the liberal world order, for it takes Asian actors' attempts at Westernisation as a part of their search for recognition as equal members of international society. Be that as it may, the International Society School does not help us understand Japan's (among others) search for security against colonial powers of the 'West' by colonising 
the 'East'. ${ }^{71}$ Critical of International Society accounts, Suzuki explains Japan's search for colonies as a part of its attempt to escape being colonised by the 'West' given the 'Janus-faced' character of European/international society'. He writes:

Many non-European states which were incorporated into European International Society in the course of European imperialism did not only witness the norms of 'toleration' and 'coexistence'. They also witnessed the European International Society which often aggressively intervened in their land in order to bring them closer to 'civilization'. ${ }^{2}$

Japan, according to Suzuki, acquired colonies partly in an attempt to become 'similar', having recognised the advantages membership of European/ international society presented in terms of justifying its own empire.

Ling offers an alternative reading of the search for 'similarity' in different parts of Asia as 'the most direct means of survival despite [its] self-denying, self-humiliating implications' ${ }^{73}$ Viewed this way, interactions with the 'West' and eventual integration into the liberal world order emerge as an instance of 'post-colonial learning' through which 'the powerless eventually learn to reconcile, synthesize, and hybridize across opposing systems thereby turning an irrational imposition of power into a rational mechanism for survival and, possibly, prosperity'. ${ }^{74}$

While puzzled by the nature as well as the pace of Asia's transformation, 'Western' IR remains oblivious to the ways in which the production of ways of thinking and doing that are 'almost the same but not quite' by Asian actors has not only changed Asia but has also altered the 'West'. Ling explains:

Elites in Asia have learned from the West by absorbing, adopting and reformulating elements of the Western other into the Asian self. Similarly, elites in the West have derived from Asia profound social, cultural, psychological, political and now economic consequences that come from their construction of the 'Oriental' Other. Each world order mirrors the other in alternating waves of hypermasculinized conquest, such as military or economic imperialism, followed by hyperfeminized exploitation, such as sex trafficking, mail-order brides, and comfort women. ${ }^{75}$

To recapitulate, after having reconsidered the often taken-for-granted 'Westernness' and 'non-Westernness' of existing ways of thinking about and doing world politics, and pointed to the ways in which viewing the two as radically 'different' is allowed by 'Western' IR, which denies its own complicity in the shaping of relations between the two, this article has looked at three examples of what is to be found when one looks beyond the spatial confines of the 'West'. Viewed together, these three examples from India, Turkey and Asia (the first a 'straightforward' military security act the reasoning behind which suggests a different explanation than provided by the literature; the second a domestic political move the security logic behind 
which requires an IR explanation not captured by the literature; the third the product of hybridity in Asia via mimicry in the attempt to survive in the liberal world order) help to reinforce the point that becoming curious about the production of 'similarity' can provide insight into 'non-Western' ways of thinking about and doing world politics. It also constitutes an alternative way of thinking past 'Western' IR - a way that assumptions of radical 'difference' and 'teleological Westernisation' do not allow.

\section{Conclusion}

Given the limits (in terms of breadth and depth) of what is known about 'non-Western' ways of thinking and doing world politics, attempting to think past 'Western' IR is a challenge. Such a task has become even more challenging as a result of the world political context characterised by the 11 September 2001 attacks and other al-Qaida-linked bombings in Bali (2002), Madrid (2004) and London (2005). While questioning one's own way of doing things is never easy it has arguably been made even more difficult by the growing perception that the 'West' is 'under attack'. Although al-Qaida has not proven to be discriminating in terms of the identity of its victims, the consequences of its actions have created the impression of a 'West' under threat by the forces of so-called 'global jihadism'. Seeking to think past 'Western' IR at such a time of perceived global insecurity is not easy. Notwithstanding the potential benefits to be accrued from self-questioning and critique, many policy makers, as well as those problem-solving theorists of IR, ${ }^{76}$ more often than not think in terms of the "next election and not the next generation ${ }^{177}$ and react by circling the wagons rather than encouraging debates. That said, the current state of global insecurity could also be viewed as a wake-up call of sorts. It is in this spirit that this article has sought to contribute to the attempt at thinking past 'Western' IR.

The article did not attempt to trace the 'Western' or 'non-Western' origins of various ideas and practices. Edward W Said advised against such attempts:

To prefer a local, detailed analysis of how one theory travels from one situation to another is also to betray some fundamental uncertainty about specifying or delimiting the field to which any one theory or idea might belong. ${ }^{78}$

Rather, the article sought to destabilise prevalent assumptions that lead one to expect to find radical 'difference' in 'non-Western' ways of thinking about and doing world politics. It also sought to encourage students of IR to be curious about 'non-Western' ways even when they seem 'similar' to the point of coming across as 'uninteresting'. The article sought to show that such seeming 'similarity' may be rooted in policies of survival shaped in an international political context characterised by an unequal division of labour and distribution of power. What is more, this may be true not only for 'nonWestern' policy making, but also for 'non-Western' scholarly studies of IR. That is to say, if 'non-Western' scholars come across as 'social science socialized' products of 'Western' IR, the domestic and international politics 
of such socialisation is worth inquiring into. Arguably such inquiry into the agency of the 'non-West' in the production of ways of thinking and doing that are 'almost the same but not quite' will allow the project of thinking past 'Western' IR to further flourish.

There is no way of knowing what IR would have looked like 'had the subject been founded in universities not by a Liberal MP in mid-Wales ... but instead by ... the admirable feminist-medic she-Chief of the Zulus'. There is also no way of knowing whether such a beginning would have allowed students of IR to think past its current 'ethnocentric, masculinized, northern and top-down character'. ${ }^{79}$ While it is fascinating to speculate about what might have been, it is also interesting to inquire into what has already been.

\section{Notes}

This article was written while the author was a fellow (2006-07) at the Woodrow Wilson International Centre for Scholars, Washington, DC. An earlier version was presented at the 48th annual convention of the International Studies Association, Chicago, IL, 28 February-3 March 2007. My thanks go to the panel convenor Mustapha Kamal Pasha as well as to Adam David Morton and Philippa Strum for comments. I would also like to thank the participants of the 'Geocultural Epistemologies' project and its convenors Arlene Tickner and Ole Waever. The ideas I have presented in this article have been shaped through project-related encounters at successive ISA meetings and workshops during 2004-07.

1 S Hoffman, 'An American social science-International Relations', Daedalus, 106 (3), 1977, pp 68 - 82; and E Krippendorf, 'The dominance of American approaches in International Relations', Millennium: Journal of International Studies, 16 (2), 1987, pp 207-214.

2 O Waever, 'The sociology of a not so international discipline: American and European developments in International Relations', International Organization, 52 (4), 1998, pp 687-727.

3 S Smith, "The United States and the discipline of International Relations: "hegemonic country, hegemonic discipline"”, International Studies Review, 4 (2), 2002, pp 67-85.

4 L Yew, The Disjunctive Empire of International Relations, Aldershot: Ashgate, 2003.

5 AM Agathangelou \& LHM Ling, 'The house of IR: from family power politics to the poisies of worldism', International Studies Review, 6 (4), 2004, pp $21-49$; and N Inayatollah \& DL Blaney, International Relations and the Problem of Difference, London: Routledge, 2004.

6 SG Neuman (ed), International Relations Theory and the Third World, London: Macmillan, 1998; CS Jones, 'Special issue: Locating the "I" in IR - disclocating Euro-American theories', Global Society, 17 (2), 2003; RA Crawford \& DS Jarvis (eds), IR - Still an American Social Science: Toward Diversity in International Thought, Albany, NY: State University of New York Press, 2001; S Chan, PG Mandaville \& R Bleiker (eds), The Zen of International Relations: IR Theory from East to West, London: Palgrave Macmillan, 2001; and AB Tickner \& O Waever (eds), Global International Relations Scholarship: Worlding Beyond the West, London: Routledge, forthcoming.

7 HK Bhabha, The Location of Culture, London: Routledge, 1994.

8 K Booth, 'Human wrongs and International Relations', International Affairs, 71 (1), 1995, p 125.

9 Unless, that is, s/he is willing to become curious about the production of 'sameness' (see below).

10 P Bilgin \& AD Morton, "Historicizing representations of "failed states": beyond the cold war annexation of the social sciences?', Third World Quarterly, 23 (1), 2003, pp 55-80.

11 E W Said, Orientalism, New York: Pantheon Books, 1978.

12 A Mazrui, 'The re-invention of Africa: Edward Said, VY Mudimbe and beyond', Research in African Literatures, 36 (3), 2005, pp 68-82.

13 But see JM Hobson, The Eastern Origins of Western Civilization, Cambridge: Cambridge University Press, 2004.

14 F Fanon, The Wretched of the Earth, New York: Groove Weidenfeld, 1963, p 102.

15 A Sen, Identity and Violence: The Illusion of Destiny, New York: WW Norton, 2006, pp 57, and esp $121-169$.

16 A theme elaborated upon by Bhabha, The Location of Culture. Sen, Identity and Violence, pp 87-88 uses the example of James Mill's History of India. Although Mill never visited India and the book was suffused with inaccuracies and misrepresentations, it was nevertheless considered for decades to be 'the Bible of every British officer' visiting the country.

17 T Mitchell, 'The stage of modernity' in Mitchell (ed), Questions of Modernity, Minneapolis, MN, University of Minnesota Press, 2003, p 13. 
18 Ibid, pp 3, 6.

19 Sen, Identity and Violence, p 57.

$20 \mathrm{Ibid}$, pp 51-55; and B Bowden, 'The river of inter-civilisational relations: the ebb and flow of peoples, ideas and innovations', Third World Quarterly, 28 (7), 2007, pp 1359-1374.

21 T Barkawi \& M Laffey, 'The imperial peace: democracy, force and globalization', European Journal of International Relations, 5 (4), 1999, pp $403-434$.

22 See, for example, SP Huntington, The Clash of Civilizations and the Remaking of World Order, New York: Simon \& Schuster, 1996; and B Lewis, 'The roots of Muslim rage', Atlantic Monthly, 17 (4), 1990, pp 17-26.

23 N Chomsky (ed), The Cold War and the University: Toward an Intellectual History of the Postwar Years, New York: New Press, 1997.

24 C Simpson (ed), Universities and Empire: Money and Politics in the Social Sciences during the Cold War, New York: New Press, 1998; and I Oren, Our Enemies and US: America's Rivalries and the Making of Political Science, Ithaca, NY: Cornell University Press, 2003.

25 See notes $1,2,3,4$ and 5 .

26 PF Bell, 'The impact of the United States on the development of social sciences in Thailand', Social Science Models and their Impact on the Third World, XX (XX), 1991, p 97 (emphasis in original).

27 Nicholas Onuf provides alternative models to explain this phenomenon. See Onuf, 'Where are the theorists?', paper presented at the European Peace Research Association Fifth General Conference, Sakarya University, Turkey, 21 - 24 August 2007.

28 MK Pasha, 'Security as hegemony', Alternatives-Social Transformation and Humane Governance, 21 (3), 1996, p 283.

29 IL Gendzier, Managing Political Change: Social Scientists and the Third World, Boulder, CO: Westview Press, 1985, p 63.

30 Ibid, pp 64, 51.

31 Oren, Our Enemies and US.

32 Quoted in RW Cox, 'Towards a post-hegemonic conceptualisation of world order: reflections on the relevancy of Ibn Khaldun', in JN Rosenau \& C Ernst-Otto (eds), Governance without Government: Order and Change in World Politics, Cambridge: Cambridge University Press, 1992, p 143.

33 See, inter alia, RBJ Walker, 'Sovereignty, identity, community: reflections on the horizons of contemporary social practice', in RBJ Walker \& S Mendlowitz (eds), Contending Sovereignties: Redefining Political Community, Boulder, CO: Lynne Rienner, 1990, pp 159-185; C Enloe, 'Margins, silences and bottom rungs: how to overcome the underestimation of power in the study of International Relations', in K Booth, S Smith \& M Zalewski (eds), International Theory: Positivism and Beyond, Cambridge: Cambridge University Press, 1996, pp 186-202; JA Tickner, 'You just don't understand: troubled engagements between feminists and IR theorists', International Studies Quarterly, 41 (4), 1997, pp 611-632; H Gusterson, 'Missing the end of the Cold War in international security', in J Weldes, M Laffey, H Gusterson \& R Duvall (eds), Cultures of Insecurity: States, Communities and the Production of Danger, Minneapolis, MN: University of Minnesota, 1999, pp 319-345; and K Booth, 'Security and self: reflections of a fallen realist', in K Krause \& MC Williams (eds), Critical Security Studies: Concepts and Cases, London: UCL Press, 1997, pp 83-119.

34 B Korany, 'Strategic studies and the Third World: a critical evaluation', International Social Science Journal, 38 (4), 1986, pp 547-562; C Thomas, 'Southern instability, security and Western concepts - on an unhappy marriage and the need for a divorce', in C Thomas \& P Saravanamuttu (eds), The State and Instability in the South, London: Macmillan, 1989, pp 174-191; and D Lemke, 'African lessons for International Relations research', World Politics, 56 (October), 2003, pp 114-138.

35 For example, 'Western' approaches to 'regional security in the Middle East' invariably take 'Western' interests as the referent, to the neglect of the concerns of regional actors. See P Bilgin, Regional Security in the Middle East: A Critical Perspective, London: Routledge, 2005.

36 Korany, 'Strategic studies and the Third World', p 115.

37 See P Bilgin \& AD Morton, 'From "rogue" to "failed" states? The fallacy of short-termism', Politics, 24 (3), 2004, pp 169-180.

38 T Mitchell, 'Deterritorialization and the crisis of modern science', in A Mirsepassi, A Basu \& F Waever (eds), Localizing Knowledge in a Globalizing World: Recasting the Area Studies Debate, Syracuse, NY: Syracuse University Press, 2003, p 157.

39 Agathangelou \& Ling, 'The house of IR', p 30.

40 T Mitchell, 'The Middle East in the past and future of social science', in DL Szanton (ed), The Politics of Knowledge: Area Studies and the Disciplines, University of California Press International and Area Studies Digital Collection, 2002, available at http://repositories.cdlib.org/uclapubs/editedvolumes/3, accessed 24 March 2004.

41 For important exceptions, see K Booth, Strategy and Ethnocentrism, London: Croom Helm, 1979; Weldes et al, Cultures of Insecurity; Krause \& Williams, Critical Security Studies; and MC Williams, 
Culture and Security: Symbolic Power and the Politics of International Security, London: Routledge, 2007.

42 There is also the group of scholars who fit the description of 'native informants'. I do not address their contributions in this section, because their role is better explained with reference to the aforementioned hierarchical division of labour. Nor do I address here the issue of how IR is structured in specific contexts, which, in turn, shapes and is shaped by its relationship with 'Western' and/or US IR.

43 D Puchala, 'Third World thinking and contemporary International Relations', in SG Neuman (ed), International Relations Theory and the Third World, London: Macmillan, 1998, p 139.

44 PG Mandaville, 'Toward a different cosmopolitanism-or, the "I" dislocated', Global Society, 17 (2), 2003, p 211.

45 See Puchala, 'Third World thinking'.

46 See Jones, 'Locating the "I" in IR'.

47 Mandaville, 'Toward a different cosmopolitanism', p 211.

48 Reference to the 1975 film, The Stepford Wives, by Bryan Forbes about a group of suburban men replacing their wives with robots with perfect skills minus all-so-human constraints.

49 Puchala, 'Third World thinking', p 139.

50 Mandaville, 'Toward a different cosmopolitanism', p 211.

51 For an attempt, see P Bilgin, 'Os estudos de segurança na Turquia: situando a Turquia no "Ocidente" por meio de "escrever a segurança", Contexto Internacional, 26 (1), 2004, pp 149-185.

52 J Han \& LHM Ling, 'Authoritarianism in the hypermasculinized state: hybridity, patriarchy, and capitalism in Korea', International Studies Quarterly, 42 (1), 1998, pp 54, 57.

53 Bhabha, The Location of Culture, $\mathrm{p} 86$.

54 LHM Ling, "Cultural chauvinism and the liberal international order: "West vs rest" in Asia's financial crisis', in G Chowdhry \& S Nair (eds), Power in a Postcolonial World: Race, Gender and Class in International Relations, London: Routledge, 2002, pp 115-141.

55 Spivak, however, warns against the search for authenticity. In Loomba's words, 'the pre-colonial is always reworked by the history of colonialism, and is not available to us in any pristine form that can be neatly separated from the history of colonialism'. A Loomba, Colonialism/postcolonialism, London: Routledge, 2005, p 21.

56 Bhabha, The Location of Culture, $\mathrm{p} 88$.

57 'Special Issue on South Asia and theories of nuclear deterrence', India Review, 4 (2), $2003-04$.

58 G Perkovich, 'Is India a major power?', Washington Quarterly, 27 (1), 1998, p 129.

59 I Abraham, The Making of the Indian Atomic Bomb: Science, Secrecy and the Postcolonial State, New York: Zed Books, 1998, p 17.

$60 \mathrm{Ibid}, \mathrm{p} 13$.

61 The absence of colonial status from Turkey's history need not render postcolonial insights less relevant. Following Jorge de Alva, postcoloniality should "signify not so much subjectivity "after" the colonial experience as a subjectivity of oppositionality to imperializing/colonizing (read: subordinating/subjectivizing) discourses and practices'. Cited in Loomba, Colonialism/postcolonialism, p 16.

62 Or 'European'. See H Kohn, 'The Europeanization of the Orient', Political Science Quarterly, 52 (2), 1937, pp $259-270$.

63 See, for example, Ç Keyder, State and Class in Turkey: A Study in Capitalist Development, London: Verso, 1987.

64 For further discussion, see P Bilgin, 'Re-thinking the securityness of secularism in Turkey', unpublished manuscript.

65 Halide Edip Adıvar cited in S Kili, The Atatürk Revolution: A Paradigm of Modernization, İstanbul: İş Bankası Yayınları, 2003, p 356.

66 For further discussion, see A Davison, Secularism and Revivalism in Turkey: A Hermeneutic Reconsideration, New Haven, CT: Yale University Press, 1998.

67 EW Said, Culture and Imperialism, New York: Knopf, 1993.

68 Said, Orientalism.

69 Space does not allow a discussion on how the Ottoman Empire had previously produced its own discourse to justify its imperial forays into its East and its West.

70 See BJ Dickson, Red Capitalists in China: The Party, Private Entrepreneurs, and Prospects for Political Change, New York: Cambridge University Press, 2003.

71 See S Suzuki, 'Japan's socialization into janus-faced European international society', European Journal of International Relations, 11 (1), 2005, pp 139-170.

72 Ibid, p 147.

73 LHM Ling, Postcolonial International Relations: Conquest and Desire between Asia and the West, Basingstoke: Palgrave, 2002, p 17.

74 Ibid, pp $17-18$.

75 Ibid, p 75. 
76 Following Cox's distinction between 'problem-solving' and 'critical theory'. See RW Cox, 'Social forces, states and world orders: beyond International Relations theory', Millennium, 10 (2), 1981, pp 126-158.

77 K Booth, 'Nuclearism, human rights and constructions of security (Part 1)', International Journal of Human Rights, 3 (2), 1999, pp 1-24.

78 EW Said, 'Traveling theory', in M Bayoumi \& A Rubin (eds), The Edward Said Reader, New York: Vintage Books, 2000, p 197.

79 Booth, 'Human wrongs and International Relations', p 125. 